\title{
Calendrier des activités (de juillet 2010 à
} juillet 2011)

\section{(2) OpenEdition \\ 1 Journals}

Édition électronique

URL : https://journals.openedition.org/cem/11508

DOI : $10.4000 /$ cem. 11508

ISSN : 1954-3093

Éditeur

Centre d'études médiévales Saint-Germain d'Auxerre

Édition imprimée

Pagination : 7

ISSN : 1623-5770

Référence électronique

«Calendrier des activités (de juillet 2010 à juillet 2011) », Bulletin du centre d'études médiévales

d'Auxerre | BUCEMA [En ligne], 14 | 2010, mis en ligne le 15 octobre 2010, consulté le 22 septembre

2022. URL : http://journals.openedition.org/cem/11508; DOI : https://doi.org/10.4000/cem. 11508

Ce document a été généré automatiquement le 22 septembre 2022.

\section{c) (†) (2)}

Creative Commons - Attribution - Pas d'Utilisation Commerciale - Partage dans les Mêmes Conditions 4.0 International - CC BY-NC-SA 4.0

https://creativecommons.org/licenses/by-nc-sa/4.0/ 


\section{Calendrier des activités (de juillet 2010 à juillet 2011)}

\section{Année 2010}

\begin{tabular}{|l|l|}
\hline 7-8 septembre & $\begin{array}{l}\text { Sens- Faïences et majoliques, } \mathrm{du} \mathrm{XV}^{\mathrm{e}} \text { au début du XVII }{ }^{\mathrm{e}} \text { siècle en France, à partir } \\
\text { des découvertes archéologiques : pour un bilan des connaissances. } \\
\text { Fabienne RAVoIRE et Alban HORRY }\end{array}$ \\
\hline 9-12 septembre & $\begin{array}{l}\text { Cluny- Cluny, le monachisme et l'émergence d'une société seigneuriale (voir } \\
\text { programme Bucema 13) }\end{array}$ \\
\hline $\begin{array}{l}30 \text { septembre-1 } \\
\text { octobre }\end{array}$ & $\begin{array}{l}\text { Dijon-Besançon - Le vocabulaire et la rhétorique des comptabilités } \\
\text { médiévales. Modèles, innovations, formalisation. Patrice BECK }\end{array}$ \\
\hline
\end{tabular}

Année 2011

\begin{tabular}{|l|l|}
\hline $\begin{array}{l}28 \\
\text { janvier }\end{array}$ & $\begin{array}{l}\text { Dijon- CBMA. Chartae Burgundiae Medii Aevi V. Actes cisterciens et prémontrés. Eliana } \\
\text { MAGNANI et Marie-José GASSE-GRANDJEAN }\end{array}$ \\
\hline $\begin{array}{l}28-29 \\
\text { avril }\end{array}$ & $\begin{array}{l}\text { Auxerre- «Les nouveaux horizons de l'ecclésiologie médiévale ». Écclésiologie et } \\
\text { hérésiologie (Moyen Âge, Temps modernes). Frédéric GABRIEL et Dominique IOGNA-PRAT }\end{array}$ \\
\hline $\begin{array}{l}\text { 13-14 } \\
\text { mai }\end{array}$ & $\begin{array}{l}\text { Dijon- Normes et anthropologie. Approches historiographiques et champs actuels de la } \\
\text { recherche. Jacques CHIFFOLEAU et Bruno LEMESLE }\end{array}$ \\
\hline $\begin{array}{l}\text { 10-11 } \\
\text { juin }\end{array}$ & $\begin{array}{l}\text { Semur-en-Auxois- Les fortifications urbaines en Bourgogne. Pierre PINON et Christian } \\
\text { SAPIN }\end{array}$ \\
\hline $\begin{array}{l}16-17 \\
\text { juin }\end{array}$ & $\begin{array}{l}\text { Auxerre- Notarum figura : l'écriture musicale et le monde des signes au IX siècle. } \\
\text { Eduardo H. AUBERT }\end{array}$ \\
\hline
\end{tabular}


3 Contact : cnrs.cem@wanadoo.fr 